\title{
EDUKASI POLITIK DALAM PELAKSANAAN \\ PEMILIHAN KEPALADAERAH (PILKADA) LANGSUNG \\ KABUPATEN KAMPAR PROVINSI RIAU TAHUN 2017
}

\begin{abstract}
One area that implements direct Regional Head Election (Pilkada) in 2017, is Kampar Regency, Riau Province. The implementation of the Kampar Regency Direct Local Election has been running three times, namely in 2006, won by the pair Burhanudin Husein and Teguh Sahono; The 2011 regional election was won by Jefry Noer and Ibrahim Ali and the latest direct election was in 2017 which was won by elected regent Aziz Zainal and Catur Sugeng Santoso. This research study focused on analyzing political education in the implementation of Direct Regional Head Elections (KILKADA) in Kampar Regency in 2017 and knowing the Barriers found in realizing political education for the community at the time of Direct Election of Regional Heads (PILKADA) in Kampar District in 2017

This type of research is to use a type of qualitative research. According to Moleong (1999: 23) said that qualitative research methods basically use an inductive approach, ie data is collected, analyzed, abstracted and theories will emerge as qualitative discoveries. In this research, it is intended to explore in depth various data and information accurately and explain or explain in more depth the subject matter discussed in accordance with the research objectives.

The results of the study indicate that the political education for the people in the Direct Local Election of Kampar Regency in 2017, which was carried out by the KPU of Kampar Regency, has been structured in accordance with the existing rules namely Election law and other rules, including the decision of the KPU of Kampar Regency. Political education that has been carried out so far is more structurally socialized, ranging from political education to the voters to community leaders and women. The obstacles faced in the implementation of the Kampar Regency Direct Local Election political education in 2017, namely geographical factors, limited budgets, community enthusiasm and limited personnel or human resources.
\end{abstract}

Keyword: Education of Politic, Political Process and Political Participate

\section{*Candra Jon Asmara}

*Dosen Fakultas Ekonomi dan Ilmu Sosial UIN Suska Riau

\section{PENDAHULUAN}

Kebijakan desentralisasi yang dibuat pemerintah pusat melalui Undang-Undang (UU) Nomor 22 Tahun 1999 tentang Pemerintahan Daerah yang direvisi menjadi UU. Nomor 32 Tahun 2004 dan terakhir menjadi UU. 23 Tahun Pilkada langsung serentak tahun 2017 dilaksankan berdasarkan Undang - Undang No.8 Tahun 2015 tentang Pemilihan Gubernur/ Wakil Gubernur, Bupati dan Wakil Bupati, dan/atau Walikota dan Wakil Walikota serentak. Untuk itu Komisi Pemilihan Umum (KPU) telah menetapkan Rabu, tanggal 15 februari 2017 sebagai pelaksanaan 
pemilihan Gubernur/ Wakil Gubernur, Bupati dan Wakil Bupati, dan/atau Walikota dan Wakil Walikota serentak pada tahun 2017 berdasarkan Peraturan Komisi Pemilihan Umum Nomor 3 Tahun 2016 tentang Tahapan, Program dan Jadwal Penyelenggaraan pemilihan Gubernur/ Wakil Gubernur, Bupati dan Wakil Bupati, dan/ atau Walikota dan Wakil Walikota serentak pada tahun 2017. KPU juga telah merilies data bahwa total daerah yang akan menyelenggarakan Pilkada berjumlah 101 daerah, yang terdiri dari 7 provinsi, 18 Kota, dan 76 Kabupaten. Daerah tersebut yang akhir masa jabatan Kepala Daerahnya berakhir dari Juli 2016 sampai dengan Desember 2016.

Salah satu daerah yang telah melaksanakan Pemilihan Kepala Daerah (Pilkada) langsung tahun 2017, adalah Kabupaten Kampar Provinsi Riau. Penyelenggaraan Pilkada Langsung Kabupaten Kampar telah berjalan sebanyak tiga kali yakni tahun 2006 dimenangkan pasangan Burhanudin Husein dan Teguh Sahono; Pilkada tahun 2011 dimenangkan pasangan Jefry Noer dan Ibrahim Ali dan Pilkada langsung yang terbaru adalah tahun 2017 yang dimenangkan oleh bupati terpilih Aziz Zainal dan Catur Sugeng Santoso.

Dengan mempertimbangkan betapa urgensinya pilkada langsung Kabupaten Kampar sebagai ajang pendidikan politik bagi masyarakat, maka sudah seharusnya pesta demokrasi yang sudah dilaksankan, sekali lagi kita manfaatkan sebenar - benarnya sebagai sarana pembelajaran politik bagi masyarakat. Media bersama komunikator politik yaitu calon pasangan kepala daerah beserta tim suksesnya dan partai pengusung juga lembaga - lembaga politik seperti KPU, Bawaslu dan lembaga lainnya yang terkait, bersatu memberikan pencerahan melalui kampanye yang jujur, adil, serta menjunjung tinggi Fair Play guna memberikan informasi yang berimbang kepada masyarakat. Jika hal tersebut dapat dicapai, maka secara otomatis tingkat pendidikan politik masyarakat dan partisipasi politik akan meningkat. Berikut ini adalah tabel rekap suara Pilkada Kabupaten Kampar 2017;
Tabel 1: Rekap Suara Pilkada Kabupaten Kampar 2017

\begin{tabular}{|c|l|c|c|}
\hline $\begin{array}{c}\text { No } \\
\cdot\end{array}$ & \multicolumn{1}{|c|}{$\begin{array}{c}\text { Nama } \\
\text { Pasangan } \\
\text { Calon }\end{array}$} & $\begin{array}{c}\text { Jumlah } \\
\text { Suara }\end{array}$ & $\begin{array}{c}\text { Persentas } \\
\mathrm{e}\end{array}$ \\
\hline 1. & AMIN-SALEH & 19,505 & 5,96 \\
\hline 2. & $\begin{array}{l}\text { ZULHER- } \\
\text { DASRIL }\end{array}$ & 90,977 & 27,80 \\
\hline 3. & AZIS-CATUR & $\begin{array}{c}106,08 \\
5\end{array}$ & 32,43 \\
\hline 4. & $\begin{array}{l}\text { JAWAHIR- } \\
\text { BARDANSYA } \\
\text { H }\end{array}$ & 11,597 & 3,54 \\
\hline 5. & $\begin{array}{l}\text { ARDO- } \\
\text { KHAIRUDDIN }\end{array}$ & 99,048 & 30,27 \\
\hline \multicolumn{2}{|l}{ Total Suara Sah } & $\begin{array}{c}327,24 \\
8\end{array}$ & 100 \\
\hline
\end{tabular}

Sumber : KPU Kabupaten Kampar, 2017

Berdasarkan tabel di atas dapat diketahui bahwa, penyelenggaraan Pilkada Kabupaten Kampar 2017 telah selesai dilaksankan sesuai dengan tahapan peleksanaan yang telah ditetapkan oleh KPUD Kabupaten Kampar. Adapun tahapan pelaksanaan Pilkada Kampar tersebut adalah sebagai berikut;

1. Persiapan dimulai dari 22 Mei 2016 - 15 Februari 2017

2. Tahapan Penyelenggaraan.

A. Syarat Dukungan Paslon Perseorangan 6 Agustus 2016 - 9 Oktober 2016

B. Pendaftaran; Pendaftaran Paslon ke KPU : 19-21 September 2016

C. Syarat dukungan Paslon Perseorangan 19 September - 9 Oktober 2016

D. Penetapan Paslon : 22 Oktober 2016

E. Pengundian dan Pengumuman nomor urut Paslon : 23 Oktober 2016

F. Sengketa TUN Pemilihan 22 Oktober - 19 Januari 2017

G. Kampanye :

- Kampanye : 26 Oktober 2016 - 11 Februari 2017

- Debat publik antas Paslon : 26 Oktober 2016 - 11 Februari 2017

- Kampanye melalui media massa dan elektronik : 29 Januari - 11 Februari 2017 


\section{Hasil Penelitian}

- Masa tenang dan pembersihan alat peraga : 12-14 Februari 2017

H. Laporan dan Audit Dana Kampanye 25 Oktober 2016 - 3 Maret 2017.

I. Pengadaan Logistik ; 3 Nopember 2016 14 Februari 2017

J. Pemungutan dan Penghitungan; 15 Februari 2017

K. Rekapitulasi 15-24 Februari 2017

L. Penetapan Paslon Terpilih tanpa PHP : 8-10 Maret 2017

M. Pengusulan pengesahan pengangkatan Paslon terpilih (tanpa PHP): 9-11 Maret

N. Evaluasi dan Pelaporan Tahapan (tanpa PHP) : 12 Maret - 13 Juni 2017.

Tahapan Pilkada Kabupaten ampar 2017 di atas sangat banyak sekali, namun yang terpenting adalah masa kampanye yang cukup lama yakni 26 Oktober 2016 - 11 Februari 2017, hal ini berarti adanya kesempatan bagi setiap Paslon (Pasangan Calon) untuk memberikan pendidikan politik (politic education) bagi masyarakat peemilih dalam rangka menyampaikan visi dan misi dari Paslon tersebut. Namun masa kampanye yang cukup lama, belum mampu memberikan edukasi politik yang baik bagi masyarakat, sehingga ditemukan berbaggai pelanggaran dalam pelaksanaan Pilkada Langsung Kabupaten Kampar 2017 dan juga ditemukan adanya PSU (Pemungutan Suara Ulang) di dua desa yakni Desa Tarai Bangun Kecamatan Tambang dan Desa Kumantan Kecamatan Bangkinang.

Pendidikan politik dari setiap penyelenggaraan pesta demokrasi, termasuk Pilkada Langsung Kabupaten Kampar 2017, merupakan salah satu cara yang dapat dilakukan untuk mencerdaskan masyarakat pemilih. Namun kenyataannya masih banyak kelemahan dalam mewujudkan pendidikan politik bagi masyarakat dalam Pilkada Langsung Kabupaten Kampar 2017. hal inilah yang menjadi fokus kajian dalam penelitian ini yang berjudul "EDUKASI POLITIK DALAM PELAKSANAAN PEMILIHAN KEPALADAERAH (PILKADA) LANGSUNG KABUPATEN KAMPAR 2017”

\section{RUMUSAN MASALAH}

Berdasarkan latar belakang masalah di atas, penulis merumuskan permasalahan penelitian ini sebagai berikut?

1. Bagaimana edukasi politik dalam pelaksanaan Pemilihan Kepala Daerah (PILKADA) Langsung di Kabupaten Kampar Tahun 2017?

2. Hambatan-Hambatan apa saja yang ditemukan dalam mewujudkan edukasi politk bagi masyarakat pada saat pelaksanaan Pemilihan Kepala Daerah (PILKADA) Langsung di Kabupaten Kampar Tahun 2017?

\section{KERANGKA TEORI}

\section{Kajian tentang Politik}

Ilmu politik menurut Sharma dalam Suhelmi (2004:7) lahir berdasarkan konsep teori imperium. Teori imperium adalah teori tentang kekuasaan dan otoritas Negara dimana kedaulatan dan kekuasaan dianggap sebagai bentuk pendelegasian kekuatan kepada penguasa Negara. Penguasa politik hanyalah lembaga yang dipercaya untuk memegang (bukan menguasai dan mendominasi) serta mempergunakan kedaulatan demi kebaikan seluruh rakyat.

Kajian ilmu politik tidak jauh berbeda dengan kajian ilmu-ilmu sosial lainnya. Namun fokus dari kajian ilmu politik adalah kekuasaan dalam suatu Negara dan proses pencapain kekuasaan tersebut. Menurut Soltau dalam Kencana dan Azhari (2005:8) Ilmu politik untuk selanjutnya akan dianggap pelajaran tentang negara, maksud dan tujuan Negara, lembaga yang melaksanakan tujuan, hubungan antar negara dan warga negaranya, serta hubungan antar negara, dan juga apa yang dipikirkan warganya. Sedangkan lebih lanjut menurut Robert A. Dahl Kencana dan Azhari (2005:8) ilmu politik adalah sudah barang tentu pelajaran tentang siasat, atau lebih baik pula dikatakan, hal ini sebagai pelajaran terinci dari berbagai cara yaitu usaha pembahasan yang teratur untuk menemukan pencegahan kebingungan yang kacau dalam pengertian yang lebih luas. Politik 
menurut Deliar Noer (1983:6) mengatakan bahwa defenisi politik adalah segala aktifitas atau sikap yang berhubungan dengan kekuasaan dan yang bermaksud untuk mempengaruhi, dengan jalan mengubah atau mempertahankan suatu bentuk susunan masyarakat. Keadaan politik disuatu negara sangat bergantung kepada sistem politik dari negara tersebut

\section{Konsep Pemilu di Indonesia}

Menurut Undang-Undang Nomor 12 Tahun 2003 pasal 1. menyatakan bahwa Pemilihan Umum yang selanjutnya disebut Pemilu adalah sarana pelaksanaan kedaulatan rakyat dalam Negara Kesatuan Republik Indonesia yang berdasarkan Pancasila dan Undang-Undang Dasar Negara Republik Indonesia Tahun 1945. Pelaksanaan Pemilu merupakan wahana untuk menyalurkan aspirasi rakyat. Pemilu di Indonesia sebelum era reformasi masih bersifat pemilihan partai politik tanpa mengetahui siapa yang duduk pada lembaga legislatif yang mengangkat kepela eksekutif. Namun setelah era reformasi berjalan tepatnya pada Pemilu 2004 maka kekuatan sepenuhnya pada rakyat untuk memilih wakil rakyat yang duduk pada lembaga legislatif dan memilih Presiden dan Wakil Presiden sebagai kepala eksekutif.

Pada umumnya pelaksanaan Pemilu menurut Kencana dan Azhari (2005:98) ada dua sistem pelaksanaan pemilihan umum yang dipakai yaitu sebagai berikut;

a. Sistem distrik; sistem ini diselenggarakan berdasarkan lokasi daerah pemilihan, dalam arti tidak membedakan jumlah penduduk, tetapi tempat yang sudah ditentukan. Jadi daerah yang sedikit penduduknya memiliki wakil yang sama dengan daerah yang padat penduduknya. Oleh karena itu sudah barang tentu banyakjumlah suara yang akan terbuang di satu pihak tetapi malahan menguntungkan pihak yang renggang penduduknya.

b. Sistem proporsional. Sistem ini didasri jumlah penduduk yang akan menjadi peserta pemilih, misalnya setiap 40.000 penduduk pemilih memperoleh satu wakil (suara berimbang), sedangkan yang dipilih adalah kelompok orang yang diajukan kontestan pemilu, yaitu para partai politik (multi member constituency) yang dikenal lewat tanda gambar (lijsten stelsel) sehingga wakil dan pemilih kurang akrab.

\section{Partisipasi Politik Masyarakat}

Menurut Mirriam Budihardjo (1982:1) pengertian partisipasi politik sebagai kegiatan seseorang atau sekelompok orang untuk ikut serta aktif dalam kehidupan politik, yaitu dengan jalan memilih pemimpin negara, dan secara langsung mempengaruhi kebijaksanaan pemerintah (public policy). Kegiatan ini mencakup tindakan seperti memberikan suara dalam pemilihan kepentingan, mengadakan hubungan contacting dengan pejabat pemerintah atau anggota parlemen dan sebagainya. Sedangkan menurut Norman H. Nee dan Sidney Verba dalam Mirriam Budihardjo (1982:2) menjelaskan bahwa partisipasi politik adalah kegiatan pribadi warga negara yang legal yang sedikit banyak langsung bertujuan untuk mempengaruhi seleksi pejabat-pejabat negara dan atau tindakan-tindakan yang diambil oleh mereka.

Dalam kajian perilaku pemilih dalam menjatuhkan pilihannya pada saat pemungutan suara, para ahli ilmu politik memberikan argumentasi tentang tingkah laku pemilih dalam pemungutan suara pada kegiatan pemilu yang disebut dengan votting behavior. Menurut Gosnell sebagaimana yang dikutif oleh Alwis (1994:18) memberikan batasan tentang votting behavior sebagai berikut " pemungutan suara adalah proses dimana seorang anggota mayarakat dari suatu kelompok menyatakan pendapatnya dan demikian ikut serta dalam menentukan consensus diantara anggota-anggota kelompok itu dalam pemilihan seorang pejabat maupun keputusan yang diusulkan.

Menurut Rauf (1992:77) menjelaskan tingah laku pemilih dibedakan menjadi dua 
pertimbangan yang digunakan para pemilih untuk menjatuhkan pilihannya pada partai politik tertentu yaitu;

1. Faktor-faktor yang berkaitan dengan kewajiban dan perasaan/sentimen, disebut sebagai party identification yang dapat tumbuh oleh banyak hal, seperti ikatan kelompok etnis, agama, ataupun tradisi, sehingga seorang pemilih merasa menjadi bagian dari organisasi sosial politik tertentu.

2. Faktor akal sehat (rasio). Dengan rasio, para pemilih dapat mempertimbangkan dengan sebaik-baiknya Organisasi Peserta Pemilu (OPP) yang akan dicoblos berdasarkan informasi yang mereka peroleh baik pada masa kampanye maupun masa-masa sebelumnya.

Menurut Sudibyo (1995:54) menjelaskan bahwa, ada lima pendekatan dalam menganalisis tingkah laku masyarakat pemilih. Kelima pendekatan tersebut adalah;

a. Structure approach, yakni struktur sosial yang dipandang sebagai basis dan pengelompokan kelompok dalam politik

b. Sociology approach, merupakan tingkah laku seseorang sangat dipengaruhi oleh identitas mereka terhadap sesuatu kelompok serta norma-norma yang dianut oleh kelompok itu.

c. Ecological approach, pendekatan ini melihat bahwa, faktor yang bersifat ekologis seperti, daerah sangat menentukan tingkah laku politik seseorang.

d. Social psychological, yakni melihat bahwa tingkah laku dan keputusan politik seseorang, sangat dipengaruhi oleh interaksi antara faktorfaktor internal seperti sistem kepercayaan dan faktor eksternal seperti pengalaman politik.

e. Rational choice approach, merupakan kelanjutan dari pendekatan social psychological. Disini orang percaya bahwa makin modern masyarakat, semakin tinggi tingkat pendidikan mereka, maka warga masyarakat akan selalu memperhitungkan keuntungan dan kerugian yang akan diperoleh bila melakukan tindakan politik

\section{Pendidikan Politik Bagi Masyarakat}

Pendidikan politik dapat diartikan sebagai usaha sadar untuk mengubah proses sosialisasi politik masyarakat sehingga mereka memahami dan menghayati betul nilai-nilai yang terkandung dalam suatu sistem politik yang ideal hendak dibangun. Hasil dari penghayatan itu akan melahirkan sikap dan tingkah laku politik baru yang mendukung sistem politik yang ideal itu dan bersamaan dengan itu pulalah kebudayaan politik baru (Aflian, 1992: 235). Gabriel. A Almond juga mengemukakan pendapatnya bahwa sosialitization/pendidikan politik menunjukan pada proses di mana sikapsikap politik dan pola-pola tingkah laku politik diperoleh atau dibentuk, dan merupakan sarana bagi generasi untuk menyampaikan patokanpatokan politik dan keyakinan politik pada generasi berikutnya.

Bentukpendidikan politik menurut Rusadi Kartaprawira (2004: 56) dapat diselenggarakan antara lain melalui:1. bahan bacaan seperti surat kabar, majalah, dan lain-lain bentuk publikasi massa yang biasa membentuk pendapat umum;2. siaran radio dan televisi serta film (audio visual media); 3. lembaga atau asosiasidalam masyarakat seperti masjid atau gereja tempat menyampaikan khotbah, dan juga lembaga pendidikan formal ataupun iniformal.

\section{MOTODE PENELITIAN}

Jenis penelitian ini adalah menggunakan jenis penelitian kualitatif. Menurut Moleong (1999:23) mengatakan bahwa metode penelitian kualitatif pada dasarnya menggunakan pendekatan induktif, yaitu data dikumpulkan, dianalisis, diabstraksikan dan akan muncul teori-teori sebagai penemuan kualitatif. Dalam penelitian ini dimaksud untuk menggali secara mendalam berbagai data dan informasi secara akurat dan menerangkan atau menjelaskan lebih mendalam dari pokok permasalahan yang dibahas sesuai dengan tujuan penelitian. Lokasi dari penelitian ini di wilayah Kabupaten Kampar Provinsi Riau. 
Penelitian ini dalam mengumpulkan data primer, dilaksankan dengan menggali informasi yang lebih mendalam dengan menentukan informan penelitian. Adapun informan dalam penelitian ini adalah; Komisioner KPU Kabupaten Kampar, anitia Panwaslu Kabupaten Kampar, Partai Politik, Badan Kesbangpol Kabupaten Kampar, Tokoh Masyarakat, Ahli Ilmu politik dan Masyarakat pemilih

\section{HASIL DAN PEMBAHASAN}

\section{Edukasi politik dalam pelaksanaan Pemilihan Kepala Daerah (PILKADA) Langsung di Kabupaten Kampar Tahun 2017}

Edukasi politik dalam Pilkada Langsung Kabupaten Kampar tahun 2017, sangat diperlukan sebagai upaya untuk meningkatkan partisipasi masyarakat pemilih dalam menyalurkan hak politik mereka, yakni hak untuk memilih Bupati Kampar Periode 2017-2022. Adapun edukasi politik yang menjadi ukuran dalam kajian penelitian ini dapat ditelusuri proses politik sebagai berikut.

a) Rekruitmen Politik Masyarakat

Rekruitmen politik merupakan bagian awal dalam proses politik untuk meningkatkan partisispasi politik masyarakat dalam Pilkada Langsung Kabupaten Kampar tahun 2017. Rekruitmen politik pada umumnya dilakukan oleh partai politik pengusung pasangan calon dalam Pilkada Langsung Kabupaten Kampar tahun 2017.

\section{b) Komunikasi Politik kepada Masyarakat}

Komunikasi secara sederhana dapat diartikan sebagai proses penyampaian pesan dari pembawa pesan kepada penerima pesan. Komunikasi politik dalam Pilkada Langsung Kabupaten Kampar tahun 2017, dimaksudkan adalah pesan-pesan politik yang disampaikan oleh setiap pasangan calon kepada masyarakat sesuai dengan visi dan misi yang disampaian. Selain komunikasi yang dilakukan oleh masing-masing pasangan calon beserta tim sukses dan partai pendukung. Komunikasi politikjuga dilakukan oleh KPU Kabupaten Kampar

c) Sosialisasi Politik bagi Masyarakat

Sosialisasi yang dilakukan oleh KPU Kabupaten Kampar dalam Pilkada Langsung Kabupaten Kampar tahun 2017, adalah sebagai berikut;

1) Sosialisasi dalam bentuk penyuluhan

Sosialisasi dalam bentuk penyuluhan yang dilakukan oleh KPU Kabupaten Kampar dalam Pilkada Langsung Kabupaten Kampar tahun 2017. Penyuluhan dilakukan kepada tokoh agama, tokoh adat, cerdik pandai, pemilih pemula dan kelompok perempuan. Penyuluhan yang dilakukan oleh KPU Kampar dilaksankan pada tanggal 12 Februari 2016 dengan mengundang tokoh-tokoh tersebut. harapan dari penyuluhan tersebut, adalah sebagai agen penyuluh kepada tokoh masyarakat untuk memberikan pemahaman kepada masyarakat diwilayah mereka masing-masing.

\section{2) Sosialisasi Melalui Media Massa Cetak}

Kegiatan sosialisasi oleh KPU Kampar melalui media cetak berdasarkan, Keputusan KPU Kampar No. 79.a/Kpts/KPU-KPR-004.435228/ XII/2016 Tentang Penetapan Nama Media Elektronik, Media Cetak dan Media On-Line Penayangan Iklan Kampanye Pasangan dalam Pemilihan Buoati dan Wakil Bupati Kampar Tahun 2017. Adapun media masa cetak yang dipilih oleh KPU Kabupaten Kampar adalah media cetak lokal, yakni Riau Pos dan Haluan Riau.

\section{3) Sosialisasi Melalui Media Massa Elektronik \\ Sosialisasi melalui media massa elektronik} yang dilakukan KPU Kabuapten Kampar, dilakukan dengan cara menerbitkan iklan sosialisasi, pengumuman-pengumuman, peraturanperaturan dan berita-berita seputar kegiatan KPU 
Kabupaten Kampar dan pelaksanaan Pilkada Langsung Kabupaten Kampar tahun 2017, melalui PT. Radio97,1 FM Radio Pratama Bangkinang, Radio Republik Indonesia (RRI) Pro 1, dan jejaring sosial dan sosialisasi melalui Riau Televisi.

\section{4) Sosialisasi Melalui Alat Peraga}

Sosialisasi melalui alat peraga yang dilakukan oleh KPU Kabupaten Kampar dalam Pilkada Langsung Kabupaten Kampar tahun 2017, sebagai berikut;

- Baliho tahapan dan jadwal sebanyak 7 buah

- Imsyakiyah ramadhan sebanyak 10.000 lembar

- Sampan hias balimau kasai menyambutbulan suci ramadhan 1 unit sampan yang digunakan pada saat balimau kasai di Desa Batu Belah Kecamatan Kampar

- Stiker maskot Pilkada Beradat(Bersih Amanah Damai Adil dan Transparan) sebanyak 200 lembar

- Poster ajakan memilih sebanyak 7.500 lembar

- Baju sosialisasi sebanyak 1000 lembar untuk PPK dan PPS

- Baju dan Topi sebanyak 1000 lembar untuk masyarakat

- Gerakan jalan santai Pilkada 2017 dengan menggunakan 3 Badut ajakan memilih bagi masyarakat.

- Topi sosialisasi dan tas sosialisasi untuk KPU, KPPK dan KPPS, sebanyak 1.000 lembar.

Sosialisasi yang dilakukan oleh KPU Kabupaten Kampar dalam Pilkada Langsung Kabupaten Kampar tahun 2017, tersusun secara terstruktur, namun partisasipasi pemilih masih belum optimal, dimana partisipasi politik masyarakat hanya mencapai 69,29 \% (Ketua KPU Kabupaten Kampar)

d) Orientasi Politik

Pendidikan politik adalah aktifitas yang bertujuan untuk membentuk dan menumbuhkan orientasi-orientasi politik pada individu. Pendidikan politik yaitu untuk meningkatkan pengetahuan rakyat agar mereka dapat berpartisipasi secara maksimal dalam sistem politik. Orientasi ini bertujuan untuk mewujudkan independensi masyarakat dalam menentukan pilihan secara rasional menurut pilihan hati nurani mereka. Keseluruhan dari proses politik diatas dapat mewujudkan orientasi politik masyarakat pemilih dalam Pilkada Langsung Kabupaten Kampar tahun 2017.

Edukasi politik yang dilaksankan dalam Pemilukada Kabupaten Kampar Tahun 2017, belum meunnjukkan hasil yang lebih biak dalam hal meningkatkan pengetahuan dan pemahaman masyarakat terhadap proses politik dalam Pilkada Langsung Kabupaten Kampar tahun 2017. Hal ini dapat dilihat dari tabel berikut ini;

\section{Tabel 2. Jumlah Daftar Pemilih Tetap dan Suara Sah Pilkada Kampar dari Tahun 2006-2017}

\begin{tabular}{|c|c|r|c|}
\hline Tahun & $\begin{array}{c}\text { Jumlah } \\
\text { DPT }\end{array}$ & Suara Sah & $\%$ \\
\hline 2006 & 385.170 & 259.909 & 67,48 \\
\hline 2011 & 486.280 & 273.118 & 56,16 \\
\hline 2017 & 480.976 & 327.248 & 68,04 \\
\hline
\end{tabular}

Sumber : KPU Kabupaten Kampar, 2017

Berdasarkan gambaran tabel di atas dapat di ketahui bahwa, edukasi politik dalam Pilkada Langsung Kabupaten Kampar tahun 2017, belum berhasil secara maksimal yang dilakukan oleh Partai Politik, Paslon dan yang utama adalah KPU Kabupaten Kampar. Jumlah pemilih dalam DPT 2011 cukup banyak, karena masih bergabung 5 desa yangmenjadi rebutan antara Kabupaten Kampar dengan Kabupaten Rokan Hulu. Namun pada tahun 2017 jumlah DPT dari 5 desa tersebut tidak termasuk lagi. Dari hasil tersebut dapat dikatakan bahwa pendidikan politik yang dilakukan selama ini, belum mampu meningkatkan partisipasi masyarakat, karena pendidikan politik yang dilakukan masih terdapat beberapa kendala atau 
hambatan, baik yang idhadapi oleh KPU Kabupaten Kampar maupun oleh partai politik yang mengusung paslon yang bertarung dalam Pilkada Langsung Kabupaten Kampar tahun 2017.

\section{Hambatan-Hambatan yang ditemukan dalam mewujudkan edukasi politk bagi masyarakat pada saat pelaksanaan Pemilihan Kepala Daerah (PILKADA) Langsung di Kabupaten Kampar Tahun 2017}

Pelaksanaan pendidikan politik dalam Pilkada Langsung Kabupaten Kampar tahun 2017 oleh KPU Kabupaten Kampar, memiliki beberapa hambatan. Adapun hambatan yang dihadapi oleh KPU Kabupaten Kampar dan PPK Kecamatan se-Kabupaten Kampar adalah sebagai berikut.

1. Faktor Geografis, yakni masih terdapatnya wilayah ataudesa yang masih terisolasi seperti diwilayah XIII Koto Kampar dan Koto Kampar Hulu serta Kecamatan Kampar Kiri.

2. Antusias Masyarakat yang kurang. Sikap apatis masyarakat yang semakin lama semakin berkembang dengan pernyataan "siapapun Bupati Kampar nasib kami sperti ini juga”

3. Keterbatasan Anggaran. Adanya rasionalisasi anggaran menyebabkan berkurangnnya anggaran bagi KPU Kabupaten Kampar dalam pelaksanaan Pilkada Langsung Kabupaten Kampar tahun 2017.

4. Keterbatasan Sumber Daya Manusia. Jumlah personel untuk melakukan sosialisasi di tingkat PPK dan PPS juga terbatas, bahkan mereka yang terpilih sebagai PPS masih banyak yang belum memahami proses dari Pilkada Langsung Kabupaten Kampar tahun 2017.

\section{KESIMPULAN}

Edukasi politik bagi masyarakat dalam Pilkada Langsung Kabupaten Kampar tahun 2017, yang dilakukan oleh KPU Kabupaten Kampar, sudah trstruktur sesuai dengan aturan yang ada yakni undang-undang tentang Pemilu dan aturan lainnya, termasuk keputusan KPU Kabupaten
Kampar. Edukasi politik yang dilakukan selama ini lebih banyak bersifat sosialisasi secara struktural mulai dari pendidikan politik bagi masyarakat pemilih hingga kepada tokoh masyarakat dan kaum perempuan. Hambatan yang dihadapi dalam pelaksanaan edukasi politik Pilkada Langsung Kabupaten Kampar tahun 2017, yakni faktor geografis, anggaran yang terbatas, antusias masyarakat dan keterbatasan personel atau sumber daya manusia

\section{DAFTAR PUSTAKA}

Alwis. 1994. Perilaku Pemilih dalam Pemilu 1992 di Dati I Riau. Jakarta : Pascasarjana Universitas Indonesia.

Haris, Syamsudin. Pemilu Langsung di Tengah Oligarkhi Partai - Proses Nominasi dan Seleksi Calon Legislatif Pemilu 2004. Jakarta : PT. Gramedia.

Deliar Noer. 1983. Pengantar Ke Pemikiran Politik. Jakarta : PT Rajawali Press

Haryanto. 1982. Sistem Politik : Suatu Pengantar. Yogyakarta: Liberty

Hatington P. Samuel. 1983. Tertib Politik didalam Masyarakat yang Sedang Berubah. Jakarta : Rajawali Pers

Kencana Inu dan Azhari. 2005. Sistem Politik Indonesia. Bandung : PT. Refika Aditama

Mardjono, Martono. 1996. Politik Indonesia (1996-2003). Jakarta : Gema Insani Press

Mirriam Budihadrjo. 1993. Dasar-Dasar Ilmu Politik. Jakarta : PT. Perintis Gramedia. 1986. Partisipasi dan Partai Politik. Jakarta : PT. Perintis Garamedia.

Moleong, Lexy J. 1999. Metodologi Penelitian Kualitatif. Bandung : PT. Remaja Rosdakarya.

Nazir. Moh, 1988. Metode Penelitian. Jakarta : Ghalia Indonesia 
Sanit, Arbi. 2002. Sistem Politik Indonesia; Kestabilan, Peta Kekuatan Politik dan Pembangunan. Jakarta : PT. RajaGrafindo Persada.

Sudibyo, M. 1995. Pemilihan Umum 1992 Suatu Evaluasi. Jakarta : CSIS

Suhelmi, Ahmad. 2004. Pemikiran Politik Barat. Jakarta : PT. Gramedia Pustaka Utama.

Surbakti, Ramlan. 1992. Memahami Ilmu Politik. Jakarta : PT. Perintis Grasindo.

Jurnal Ilmu Sosial dan Ilmu Politik Universitas Riau Edisi 1 Januari 2001. Pekanbaru.
Undang-undang Nomor 31 Tahun 2002 tentang Partai Politik dan undang-Undang Nomor 12 Tahun 2003 tentang Pemilihan Umum. Jakarta : CV Eka Jaya

Himpunan Perundang-Undangan Republik Indonesia, 2005, Undang-Undang Otonomi Daerah Perimbangan Keuangan antara Pusat dan Daerah, Bandung : Nuansa Aulia.

Republik Indonesia, 1999, Undang-Undang Otonomi Daerah 1999, Sinar Jakarta : Grafika 